\title{
Artificial Intelligent Service Quality to Increase Customer Satisfaction and Customer Loyalty (Survey of PT. Telkomsel Customers)
}

\author{
Syaeful Alam \\ Magister Management \\ Telkom University \\ Bandung, Indonesia \\ syaifuley@yahoo.com
}

\begin{abstract}
This study aims to explain and determine the effect of service quality on customer satisfaction and customer loyalty. This research was conducted at PT. Telekomunikasi Selular (PT. Telkomsel) and the population used are customers who have used Telkomsel's Intelligent Artificial services. The sample used in this study amounted to 386 respondents. The independent variables used in this study are physical evidence, reliability, responsiveness and assurance. In the $F$ Test it can be seen that the service quality variable has a significant influence together with the variables of customer satisfaction and customer loyalty that is F-count on customer satisfaction with a value of 375 and customer satisfaction with a value of 675 is greater than the F-table with a value of $3,019 . \mathrm{H1}$ is the quality of service has a positive influence on customer satisfaction. The $\mathrm{H} 1$ hypothesis is accepted because the resulting $t$-count value of 17.19 is greater than t-table (1.96) with a significant level of $95 \%$ or a $5 \%$ confidence level. $\mathrm{H} 2$ is the quality of service has a positive influence on customer loyalty. The $\mathbf{H} 2$ hypothesis is accepted because the resulting T-count value of 14.00 is greater than $t$ table (1.96) with a significant level of $95 \%$ or a $5 \%$ confidence level. $\mathrm{H3}$ is customer satisfaction has a positive influence on customer loyalty where the $\mathrm{H3}$ Hypothesis is accepted because the T-test value generated is 5,999 greater than t-table (1.96) with a significant level of $95 \%$ or a $5 \%$ confidence level.
\end{abstract}

Keywords: customer satisfaction, customer loyalty, Telkomsel, reliability, responsiveness and assurance

\section{INTRODUCTION}

In the service sector, it seems that there will be a change due to an increase in service to customers to provide clear and fast information. Rapidly developing technology for the better, smarter, smaller, and cheaper will change almost all service sectors [1] especially the existence of artificial intelligent technology (AI). There are several benefits in using AI technology in serving customers, namely:

a. Business managers and researchers anticipate that the main benefits of AI and "big data" will be service innovations that create new value propositions $[2,3,4]$.

b. On a macro scale, in a market economy, the cost savings from moving service delivery from front-line employees to service robots can be assumed to be largely competitive and lead to lower prices, increased consumption and improved living standards. c. The services provided by robots have the potential to dramatically improve the quality and availability of services that are currently expensive

d. Robotic services are basically able to feel, process, and record the world around them [5] so that it allows them to record anything and everything with small details so that they can be used for service development.

PT. Telekomunikasi Selular (PT.Telkomsel) is a company in the field of telecommunications. Telkomsel introduces virtual assistant customer service using Artificial Intelligent technology on August 24, 2017. Telkomsel Virtual Assistants provide service information about products and promos quickly. Until the end of 2018, 2,032,444 active users were divided into several channels, namely Line, Facebook messenger, Telegram, Web Telkomsel.com and Grapari. When the customer has completed an interaction or transaction through Telkomsel's Virtual Assistant, the customer can make an assessment. The customer value is called the Customer Experience Survey (CES). The CES value for 2018 given by customers is at an average of 3.48 where the target given by the company is 4.00 so the CES value is still below the target. If you look at the data churn using Telkomsel's virtual assistant survived 2017 and 2018, in 2018 the monthly average was above 53\%, an increase which in 2017 had an average of $43 \%$. Based on the above data, it is necessary to conduct research on the performance of Telkomsel's virtual assistant in order to increase customer satisfaction so that customers become loyal By looking at the description above, it can be concluded that the virtual assistant service that has artificial intelligence technology needs to evaluate and improve so that the quality of service increases so that the company's image of customer trust will also increase. Based on the description, the questions raised in this study are:

1. How big is the assessment of service quality, customer satisfaction and customer loyalty according to Telkomsel's virtual assistant?

2. How does the quality of service affect customer satisfaction and loyalty of Telkomsel Virtual Assistants?

3. How does customer satisfaction influence customer loyalty in Telkomsel Virtual Assistance? 
4. Does service quality, customer satisfaction and customer loyalty influence simultaneously in using Telkomsel's Virtual Assistant?

\section{MATERIALS AND METHODS}

\section{A. Literature Review}

\section{Marketing}

According to Kotler and Keller [6], marketing is an organizational function and a set of processes for creating, communicating, and conveying value to customers and to manage customer relationships in ways that benefit the organization and its stakeholders. There are three main market forces in the new marketing reality: Technology (At present the market is affected by technology, the pace of change and the scale of technological achievement can be staggering. The number of mobile phone production is increasing and the number of people who have accessed the internet is increasing so that e-commerce, mobile Internet, and Web penetration in the market); Globalization (Globalization has made the country more multicultural. The world has become a smaller place. Transportation, shipping, and new communication technology have made it easier for us to know other parts of the world, to travel, to buy and sell anywhere. Globalization changes innovation and product development when companies take ideas and lessons from one country and apply them in another); Social responsibility (Poverty, pollution, lack of water, climate change, war, and concentration of wealth demand our attention. The private sector takes some responsibility for improving living conditions, and companies throughout the world have increased the role of corporate social responsibility).

\section{Consumer Behavior}

According to Kotler and Armstrong [7] consumer behavior is the buying behavior of end consumers, both individuals and households who buy products for personal consumption. The main objective of marketers is to serve and satisfy the needs and desires of consumers, so marketers need to know how consumer behavior in an effort to satisfy the needs and desires of consumers [8].

\section{Quality Of Service}

According to Goetsch \& Davis in [9], quality is a dynamic condition associated with products, human resource services, processes, and the environment that meets or exceeds expectations. Quality of service is a skill that can be utilized to meet expectations. According to Fandy and Chandra [9] service quality can be realized through meeting the needs and desires of customers and the accuracy of delivery to balance customer expectations.

There are five dimensions of service quality according to Parasuraman, Zeithaml and Berry in [9], namely: Reliability (Namely the company's ability to provide accurate services from the first time without making any mistakes and delivering services in accordance with the agreed time); Capture Power (Namely the willingness and ability of employees to help customers and respond to their requests, and inform when services will be provided and then provide services quickly); Guarantees (Namely the behavior of employees able to foster customer confidence in the company can create a sense of security for customers); Empathy (That is, the company understands the customer's problems and acts in the best interests of the customer, and gives personal attention to customers and has comfortable operating hours); Physical Proof (That is related to the attractiveness of physical facilities, equipment and materials used by the company and the appearance of employees).

\section{Customer Satisfaction}

According to Kotler and Keller [6] satisfaction is someone's happy or disappointed feelings that result from comparing the performance (or results) of a product or service that is felt with expectations. To measure customer satisfaction is to look at the performance or experience of customers for a product or service if it fails and does not match expectations, the customer is not satisfied, but if it is in line with expectations, the customer is satisfied and even if it exceeds expectations, the customer is very satisfied or happy.

\section{Customer Loyalty}

Loyalty is a commitment that is held firm to repurchase or repopulate products or services that are approved in the future regardless of situational influences and potential marketing efforts [6]. According to Griffin and Herres [10], loyal customers have characteristics: Make regular purchases, Buying outside the product / service line, Recommend other products, Demonstrate immunity from power Pull similar products from competitors.

\section{Artificial Intelligence}

Artificial intelligence is a part of computational science that focuses on making machines and program intelligence [11]. The following AI criteria can meet customer expectations: Understand the contents of customer messages, Engage in automatic dialogue, Give the right answer, React and help quickly becomes much easier.

\section{B. Formulation Of Hypotheses}

Based on the previous literature reviews, we formulated the following hypotheses. The relationship between the hypotheses are shown in Fig.1.

H1: Service quality has a positive effect on customer satisfaction

$\mathrm{H} 2$ : Service quality has a positive effect on customer loyalty

H3: Customer satisfaction has a positive influence on customer loyalty

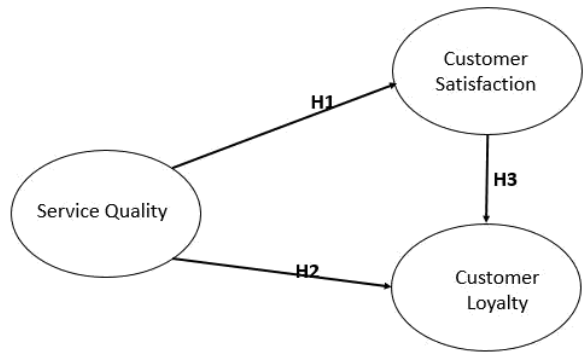

Fig 1. Hypothesis model 
TABLE 3 RESPONDENTS' ASSESSMENT OF COSTUMER LOYALTY

\section{Research methods}

This study uses a quantitative approach. The probability sampling technique used is the simple random sampling method, which is a sampling technique for population members conducted randomly without regard to the levels contained in the population. The research was conducted at the Cellular Telecommunications company. A sample of 386 respondents collected data using a questionnaire that was analyzed using smartpls.

\section{RESULTS AND DISCUSSION}

\section{A. Assessment using Telkomsel's Virtual Assistant}

To calculate the assessment of service quality, customer satisfaction and loyalty using Telkomsel's Virtual Assistant according to the customer, first we determine the ideal score / criterion. With 386 respondents and there are alternative answers with the number 5 (Strongly Disagree, Disagree, Not Agree, Agree, strongly agree):

a. The ideal service quality score $=5 \times 5 \times 386=9,650$

b. The ideal score of customer satisfaction $=5 \times 5 \times 386=$ 9,650

c. The ideal score of customer loyalty $=5 \times 4 \times 386=$ 7,720

Based on Table 1 data, it can be seen that the quality of service $=8210 / 9,650=0.85=85 \%$, so the assessment of service quality is $85 \%$ than expected. $100 \%$ expected results. Based on Table 2 data it can be seen that customer satisfaction $=8180 / 9650=0.85=85 \%$, so the assessment of customer satisfaction is $85 \%$ than expected. $100 \%$ expected results. Based on Table 3 data it can be seen that customer loyalty $=6499 / 7720=0.84=84 \%$, so the assessment of customer loyalty is $84 \%$ than expected. $100 \%$ expected results.

TABLE 1 RESPONDENTS' ASSESSMENT OF SERVICE QUALITY

\begin{tabular}{ccccccc}
\hline & SD & D & NA & A & SA & TOTAL \\
\hline SQ1 & 7 & 18 & 186 & 580 & 815 & 1606 \\
SQ2 & 5 & 28 & 192 & 652 & 700 & 1577 \\
SQ3 & 1 & 10 & 75 & 604 & 1020 & 1710 \\
SQ4 & & 10 & 159 & 644 & 835 & 1648 \\
SQ5 & 2 & 14 & 123 & 600 & 930 & 1669 \\
& & & TOTAL & & & 8210 \\
\hline
\end{tabular}

TABLE 2 RESPONDENTS' ASSESSMENT OF COSTUMER SATISFACTION

\begin{tabular}{ccccccc}
\hline & SD & D & NA & A & SA & TOTAL \\
\hline CS1 & 2 & 16 & 126 & 572 & 955 & 1671 \\
CS2 & & 20 & 153 & 620 & 850 & 1643 \\
CS3 & & 10 & 156 & 588 & 910 & 1664 \\
CS4 & 4 & 38 & 228 & 616 & 665 & 1551 \\
CS5 & & 16 & 135 & 660 & 840 & 1651 \\
& & \multicolumn{2}{c}{ TOTAL } & & & 8180 \\
\hline
\end{tabular}

\begin{tabular}{|c|c|c|c|c|c|c|}
\hline & SD & D & NA & $\mathbf{A}$ & SA & TOTAL \\
\hline CL1 & & 16 & 204 & 684 & 695 & 1599 \\
\hline CL2 & & 20 & 201 & 660 & 720 & 1601 \\
\hline CL3 & & 18 & 138 & 616 & 885 & 1657 \\
\hline CL4 & 1 & 22 & 168 & 556 & 895 & 1642 \\
\hline \multicolumn{6}{|c|}{ TOTAL } & 6499 \\
\hline
\end{tabular}

These promising results are in accordance with the theory According to Kotler and Keller $(2015,153)$ namely satisfaction is someone's feeling of pleasure or disappointment that results from comparing the performance (or results) of the product or service perceived with expectations. With the value of good service quality so that it is able to exceed customer expectations, resulting in customers being very satisfied and happy.

As the high value given by customers to customer satisfaction can have a good effect on customer loyalty, this is in accordance with the theory of customer satisfaction relationships to customer loyalty according to Hill and MacDougan in [9] that illustrates the higher customer satisfaction, the higher the customer loyalty.

B. How service quality influence customer satisfaction and loyalty of Telkomsel Virtual Assistants

According on the Table 4 data, the service quality variable has a significant effect of 0.813 on customer satisfaction, meaning that there is a positive effect between service quality on customer satisfaction and every 1 time increase in service quality is predicted to increase 0.813 times customer satisfaction with the assumption that the intellectual model does not change.

Service quality variable has a significant effect of 0.764 on customer loyalty, meaning that there is a positive influence between service quality on customer loyalty and every one time increase in Service Quality is predicted to increase 0.764 times customer loyalty with the assumption that the intellectual model does not change.

\begin{tabular}{|c|c|}
\hline & Original Sample \\
\hline SQCS & 0.813872 \\
\hline QSCL & 0.764303 \\
\hline CSCL & 0.758125 \\
\hline
\end{tabular}

From Table 5, it can be seen the R-Square value for customer satisfaction (CS) is 0.662 meaning that the Service quality variable (SQ), customer satisfaction variable (CS) and customer loyalty variable (LP) are able to explain customer satisfaction (CS) by $68 \%$ while R-Square value for customer loyalty is 0.778 indicating that the variable service quality (SQ), customer satisfaction (CS) and customer loyalty (CL) is able to explain the customer loyalty variable (CL) of $78 \%$.

a. H1: Quality of service has a positive influence on customer satisfaction can be interpreted $\mathrm{H} 1$ hypothesis is accepted because the resulting t-test value of 17.19 is 
greater than t-table (1.96) with a significant level of $95 \%$ or a $5 \%$ confidence level. Based on the results of the analysis concluded that service quality has a significant positive effect on customer satisfaction variables.

b. H2: Quality of service has a positive influence on customer loyalty, it can be interpreted as $\mathrm{H} 2$ hypothesis is accepted because the t-test value generated is 14.00 greater than t-table (1.96) with a significant level of $95 \%$ or a $5 \%$ confidence level. Based on the results of the analysis it was concluded that service quality has a positive and significant effect on customer loyalty variables.

TABLE 5 STATISTICAL TEST RESULTS - R SQUARE

\begin{tabular}{cc}
\hline & Original Sample \\
\hline SQ & - \\
CS & 0.662388 \\
CL & 0.778202 \\
\hline
\end{tabular}

From the above results, it is explained that service quality has a positive and significant impact on customer satisfaction and customer loyalty. This is according to Ismail's research, Yunan (2016) states that the conclusion of service quality is significantly correlated with customer satisfaction and customer loyalty. These findings explain that the ability of service providers to properly implement the dimensions of service quality can increase customer satisfaction and customer loyalty.

\section{How customer satisfaction influence customer loyalty in} Telkomsel Virtual Assistance

Based on Table 6 it can be seen that H3: Customer satisfaction has a positive influence on customer loyalty. It can be interpreted that the $\mathrm{H} 3$ hypothesis is accepted because the resulting t-test value of 5.999 is greater than ttable (1.96) with a 95\% significance level or a $5 \%$ confidence level. Based on the results of the analysis concluded that service quality has a significant positive effect on customer loyalty variables The customer satisfaction variable is used to measure customer satisfaction parameters related to service quality. Variable customer satisfaction has a positive effect on customer loyalty. If the customer's expectations are met so that the customer will be loyal to the Telkomsel virtual assistant. This is consistent with [9] which illustrates that the higher the customer satisfaction, the higher the customer loyalty.

TABLE 6. STATISTICAL TEST RESULTS

\begin{tabular}{lcl}
\hline & Original Sample & Status \\
\hline SQCS & 17.199186 & Accepted \\
SQCL & 14.007478 & Accepted \\
CSCL & 5.999274 & Accepted \\
\hline
\end{tabular}

D. Does the quality of service, customer satisfaction and customer loyalty influence simultaneously (together) in using Telkomsel's Virtual Assistant.

In the F-Test to find out whether there is influence together (simultaneously) the independent variables on the dependent variable. the value of F-count on the variable customer satisfaction is 375 and the value of customer loyalty is 671 where the value is greater when compared with the value of F-table 3.019 so that the service quality variable has a significant influence together with customer satisfaction and customer loyalty variables.

This means that the higher the quality of service, the higher customer satisfaction and loyalty, or vice versa if the quality of service is lower, customer satisfaction and loyalty will be lower. This is consistent with research conducted by Solimun [12] that companies must maintain the quality of company services in order to provide high levels of customer satisfaction that can cause customer loyalty.

\section{CONCLUSION}

\section{A. Conclusion}

Based on the results of research and discussion that answers all research questions about the quality of artificial intelligent services to improve customer satisfaction and customer loyalty, conclusions can be made.

Service quality, customer satisfaction and loyalty using Telkomsel's Virtual Assistant according to the customer. Assessments given by customers regarding service quality, customer satisfaction and customer loyalty using Telkomsel's Virtual Assistant services get good expectations from customers with a value above $84 \%$.

How does service quality influence customer satisfaction and loyalty of Telkomsel Virtual Assistants. Service quality variables have a positive and significant effect on customer satisfaction and customer loyalty.

How does the influence of customer satisfaction on customer loyalty Telkomsel Virtual Assistant. The customer satisfaction variable has a positive and significant effect on customer loyalty.

Does service quality simultaneously influence (together) on customer satisfaction and customer loyalty. Service quality variables have a significant influence together with customer satisfaction and customer loyalty variables.

\section{B. Suggestion}

For practical advice, it is concluded that service quality has a positive and significant impact on customer satisfaction and customer loyalty, so it must be maintained and increased service quality so that customer satisfaction and loyalty is getting better.

Service quality has a significant influence together with customer satisfaction and customer loyalty, so it must maintain the quality of service so it does not become a decline that affects customer satisfaction and loyalty.

The quality of service in the display of avatars is in the good category of $78 \%$ but there is a percentage of $22 \%$ of customers who do not agree with the current avatar display so it is necessary to do further and extensive research on the appearance of the Telkomsel Virtual Assistant avatar so that customers are comfortable viewing the avatar display.

Customer satisfaction for service answer items with complex questions about the product gets a percentage of 
$73 \%$ but there are $27 \%$ who disagree so that further research needs to be done in order to find out some of the problems and can be solved to customers

For academic advice, with the development of technology, further research is expected to further develop factors that can be further studied regarding the effect of service quality on customer satisfaction and customer loyalty.

\section{REFERENCES}

[1] Wirtz J, Zeithaml V. Cost-effective service excellence. Journal of the Academy of Marketing Science. 2018 Jan 1;46(1):59-80, 2018.

[2] Hartmann PM, Zaki M, Feldmann N, Neely A. Capturing value from big data-a taxonomy of data-driven business models used by startup firms. International Journal of Operations \& Production Management. 2016 Oct 3.

[3] Huang MH, Rust RT. Artificial intelligence in service. Journal of Service Research. 2018 May;21(2):155-72.

[4] Mayer-Schönberger V, Cukier K. Big data: A revolution that will transform how we live, work, and think. Houghton Mifflin Harcourt; 2013.

[5] Calo MR. 12 robots and privacy. Robot ethics: The ethical and social implications of robotics. 2011 Dec 9:187.

[6] Kotler P, Keller KL. Marketing management, global edition. Pearson Education UK; 2015.

[7] Kotler P, Armstrong G. Marketing: an introduction. Engle Wood Cliffs. 2000.

[8] Ratih H. Bauran pemasaran dan loyalitas konsumen. Bandung: Alfabeta. 2005.

[9] Fandy T, Chandra G. Service Quality dan Satisfaction, fourth edition. Andi Yogyakarta. 2015.

[10] Griffin J, Herres RT. Customer loyalty: How to earn it, how to keep it. San Francisco, CA: Jossey-Bass; 2002 Sep.

[11] Pottala M. Artificial Intelligence: Artificial Intelligence in Sports. 2018.

[12] Solimun S, Fernandes AA. The mediation effect of customer satisfaction in the relationship between service quality, service orientation, and marketing mix strategy to customer loyalty. Journal of Management Development. 2018 Feb 12. 